\title{
AZ ORIGINALITÁS MÉRŐ ÉS BECSLŐ MÓDSZEREINEK KONKURENS VALIDITÁSA
}

\section{Szerzők:}

Mező Ferenc

Eszterházy Károly Egyetem

Mező Katalin

Debreceni Egyetem

Szerző e-mail címe:

ferenc.mezo1@gmail.com
Lektorok:

Koncz István

PEME

Szilágyi Barnabás

Debreceni Egyetem

Kelemen Lajos

Poliforma Kft.

Nemes Magdolna

Debreceni Egyetem

Mező Ferenc, Mező Katalin (2017): Az originalitás mérő és becslő módszereinek konkures validitása. Különleges Bánásmód, III. évf. 2017/3. szám, 27-38. DOI 10.18458/KB.2017.3.27

\begin{abstract}
Absztrakt
Jelen tanulmányban az originalitás mérésének és becslésének módszertani problémáira fókuszálunk. Az első részben bemutatunk néhány tesztekben alkalmazott pontozási szisztémát, majd rámutatunk a becslőskálák alkalmazásának lehetőségeire, buktatóira. A második részben egy konkurens validitás vizsgálatot $(n=127)$ mutatunk be. Alkalmazott tesztek és változók: a Tóth-féle Kreativitást Becslő Skála (TKBS), a Szokatlan használat teszt és a Körök teszt originalitást mérő változói. Eredmények: $k b . r=0,2$ szignifikáns $(p \leq 0,05)$ korreláció volt az originalitás pontok között - ez nem elég a konkurens validitás szempontjából.
\end{abstract}

Kulcsszavak: originalitás, kreativitás, validitás

Diszciplína: pszichológia

\section{Abstract \\ CONCURRENT VALIDITY OF MEASURING AND ESTIMATING METHODS OF THE ORIGINALITY}

In this study we focus on the methodological problems of measurement and estimation of originality. At the first part, we introduce some score systems which are applied by creativity tests, and we highlight to the possibilities and the dangerous sides of estimation scales of originality. The second part of this study shows on a concurrent validity examination $(n=127)$. Applied tests and variables are: originality indexes of the Tóth's Estimation Scale of Creativity (TKBS) and the Unusual uses and the Circles tests. Results: about $r=0,2$ significant $(p \leq 0,05)$ correlations were among the originality scores - it is not enough from aspect of concurrent validitation.

Keywords: originality, creativity, validity 


\section{Disciplines: psychology}

Az originalitás a leggyakrabban vizsgált kreativitásváltozók egyike. E képesség a mindennapokban vagy a teszt-szituációkban nyújtott újszerü, szokatlan teljesítményekben manifesztálódhat. Amikor egy személy originalitását próbáljuk mérni vagy megbecsülni, akkor a következő lehetőségekkel számolhatunk. Egyrészt megfigyelés, interjú révén gyüjthetünk információkat az adott személy aktuális vagy korábbi (élettörténetében fellelhető) teljesítményeiröl. Ha ez nem lehetséges (mivel nincs megfigyelhető vagy felidézhető „originális" teljesítménye az illetőnek, vagy a kutató időbeli, anyagi lehetőségei korlátozottak), akkor olyan pszichológiai adatgyüjtési módszerek alkalmazhatók, mint a kreativitástesztek vagy kérdőívek. Az eredetiséget (is) vizsgáló tesztek lehetőséget próbálnak adni originális teljesítményekre miközben a vizsgálati személyektől újszerü, szokatlan ötleteket, megoldásokat várnak el. A kérdőívek pedig sok esetben önjellemző módon a vizsgálati személyek véleményére, élményeire kérdezve gyűjtenek adatokat, s kísérlik megbecsülni az originalitást.

$\mathrm{Az}$ alábbi sorokban először az originalitás becslésének és mérésének problémáira fókuszálunk, majd bemutatjuk saját vizsgálati eredményeinket (Mező, 2013 alapján).

\section{Az originalitás mérése tesztekkel}

Néhány szerző szerint az originalitás tesztelhető változó. Gondoljunk például olyan tesztekre, tesztcsomagokra, mint a „Guilford Battery” (Guilford, 1962); a „Torrance Tests of Creative Thinking” (TTCT - Torrance, 1966. Megjegyzés: a TTCT 1966-os léterhozása óta már négy alkalommal - 1974-ben, 1984-ben, 1990-ben és 1998-ban - került átértékelésre); a Mednick-féle Távoli Asszociációs Tesztre (Remote Associates Test - Mednick, 1962); Wallach és Kogan (1965) tesztjére; az „Insight Problems” tesztre (Dow és Mayer, 2004), stb. Lényegében az imént felsorolt tesztek originalitás méréséhez hasonló metódust alkalmaznak az olyan projektív személyiségvizsgálatok is, mint például: a Rorschach-próba (vö.: Mérei, 2002); a Fa-rajz teszt (vö.: Süle, 1988); Metamorfózisok teszt (vö.: Szönyi, 1988).

$\mathrm{Az}$ originalitás mérésére (is) alkalmasnak gondolt tesztek közül talán a legismertebb Guilford „Alternatív Használat Feladat”-a (Alternative Uses Task - Guilford, 1967). A továbbiakban ezt a tesztet/feladatot hozzuk fel példaként, hogy rámutassunk az originalitás néhány mérési problémájára. E választásunknak két oka van:

- az Alternative Uses Task egy világszerte népszerü kreativitásteszt;

- más kreativitástesztek (többek között Guilford és Torrance tesztjei) érétkelésükben hasonlóak ehhez, így e teszt alkalmas az originalitás általános mérési problémának demonstrálására.

Guilford „Alternatív Használat Feladat”-ában a vizsgálati személyeket arra kérik, hogy olyan hétköznapi tárgyakkal kapcsolatban, mint például egy tégla, találjanak ki minél több szokatlan felhasználási lehetőséget. E feladat a fentebb említett TTCT-ben „Unusual Uses” (Szokatlan használat) altesztként szerepel, s a kreatív gondolkodás négy komponensét méri. Ezek a következők: fluencia (folyékony gondolkodás, ötletgazdagság; pontozása az értékelhető válaszok száma alapján történik); originalitás (eredeti gondolkodás; pontozása az egyes válaszok előfordulásának ritkaságán alapul); flexibilitás (rugalmas, szempontváltásra kész gondolkodás; pontozása az alapján történik, hogy hány kategóriába sorolhatók a tesztre adott válaszok); elaboráció (egy adott válasz kidolgozottsága). Magyarországon e feladat a TTCT részeként „Szokatlan használat tesztként” ismert és használt már több mint húsz éve (Zétényi, 1989a,b). De: az originalitás esetében a magyar pontozási rendszer különbözik az eredeti pontozási metódustól. Az alábbiakban vizsgáljuk meg közelebbröl e különbséget! 
Guilford originalitásra vonatkozó pontozási rendszerében az egyes válaszokat a vizsgálati csoport által adott válaszok összességével kell összehasonlítanunk. Az összevetés eredményeként 2,1 vagy 0 ponttal értékelhetjük a kreativitástesztre érkezett válaszokat az alábbiak szerint:

2 pont: egy válasz originalitás értéke 2 pont lesz, ha e választ a vizsgált csoport maximum $1 \%$-a adta. Az ilyen válasz egészen egyedinek tekinthető.

1 pont: ha egy válasz a vizsgálat csoport maximum 5\%-ánál fordul elö, akkor az 1 pontot ér.

0 pont: minden egyéb esetben a válaszhoz rendelhetö originalitás érték 0 pont. Ezek azok a válaszok, amelyeket a vizsgálati csoport több, mint 5\%-a adott.

Az originalitás pontszám a válaszokra adott pontszámok összege - tehát a magasabb érték utal a nagyobb originalitásra. E pontozási rendszer előnye egyrészt egyszerüségében rejlik, másrészt abban, hogy a kvalitatív különbségeket kvantitatív értékeket alkalmazva jeleníti meg. Ugyanakkor e pontozási rendszernek van legalább két kritikus pontja: a) a fluencia befolyásolja az originalitás pontszámának értékét; b) az alkalmazott százalékos értékek igen relatívak.

Az első probléma tehát az, hogy a magasabb originalitás pontszám a magasabb fluencia (vagyis: több válasz) egyfajta mellékhatásaként is jelentkezhet. Ha valaki sok választ ad a kreativitástesztben, akkor magas fluencia értéket fog kapni, s egyben annak esélye is növekszik, hogy magasabb originalitás pontszáma lesz. Az originalitás pontszám tehát nem egészen független a fluencia pontszámától. Más szavakkal: ez az originalitás érték nemcsak az eredetiséget, hanem az originalitás és a fluencia egy sajátos kombinációját mutatja. E validitási probléma azonban elkerülhető, ha az originalitás egy korrigált számítási módját alkalmazzuk, miszerint: átlagos originalitás = originalitás/fluencia. Az alábbiakban négy példát mutatunk be az átlagos originalitás alkalmazásának demonstrálása érdekében:

a) Tegyük fel, hogy „A” személy 30 értékelhető választ adott a Szokatlan használat tesztre. Ez azt jelenti, hogy fluencia pontszáma $=30$. Ha minden válasza egyedi volt (vagyis társai kevesebb mint 1\%-ban adtak az övéhez hasonló válaszokat), akkor az originalitás pontszáma $30 \times 2$ pont $=60$ pont lesz; átlagos originalitás (=originalitás/fluencia) pontszáma pedig: $60 / 30=2$ pont. Láthatjuk, hogy amikor a Guilford-féle pontozási rendszert használjuk, akkor az originalitás összpontszám maximum értéke a fluencia pontszám kétszerese lesz; míg az átlagos originalitás maximuma 2 pont lesz.

b) Képzelüjk el, hogy „B” személy szintén 30 értékelhető választ adott a vizsgálat során vagyis az ő fluencia pontszáma is 30 lesz. Ugyanakkor „B” személynek 10 darab egyedi válasza volt $(10 \times 2$ pont $=20$ pont $) ; 10$ darab 1 pontot érő válasza volt $(10 \times 1=10$ pont) és 10 darab 0 pontos válasza volt $(10 \times 0=0$ pont). Originalitás pontszáma így: 20 $+10+0=30$ pont lesz. Ezek alapján pedig „B” átlagos originalitás pontszáma: originalitás/fluencia $=30 / 30=1$ pont. Vegyük észre, hogy noha „A” és „B” fluencia pontszáma egyenlő, „A” válaszai mégis eredetibbek, mint „,B” válaszai.

c) „C” személy esetében 15 értékelhető választ (= fluencia pontot) feltételezzünk! Válaszai között legyen 12 darab igen egyedi válasz $(12 \times 2$ pont $=24$ pont $), 3$ darab 1 pontot érö válasz $(3 \times 1$ pont $=3$ pont $)$ és 0 darab 0 pontos válasz. Originalitás pontszáma így $24+$ $3+0=27$ pont lesz. Átlagos originalitás pontszáma pedig a következőképpen alakul: originalitás/fluencia $=27 / 15=1,8$ pont. Láthatjuk, hogy noha „C”-hez képest „B” fluencia és originalitás pontszáma is magasabb volt, mégis „C" átlagos originalitás értéke a nagyobb! „C” kevesebb, de eredetibbnek számító választ adott, mint „B”. Az átlagos originalitás pontszám jobban kifejezi a minőségi és mennyiségi különbségeket, mint az egyszerü originalitás pontszám. 
d) Képzeljünk el végül egy „D” személyt, akinek 30 értékelhető válasza egyben 30 pontot jelent a fluencia tekintetében, ám e válaszok mindegyike 0 pontot ér. Originalitás értéke tehát: $30 \times 0=0$ pont; átlagos originalitás érétke pedig: originalitás/fluencia $=0 / 30=0$ pont. Az ő példája mutatja, hogy a Guilford-féle pontozási rendszerben az originalitás és az átlagos originalitás minimum értéke: 0 pont.

Az eredeti pontozási rendszer másik problémája a százalékos értékek alkalmazásában rejlik. Kérdés ugyanis, hogy milyen csoportot tekintünk referenciacsoportnak a százalékok számításakor. Például: amikor a „Szokatlan használat” feladatot egy adott csoport esetében alkalmazzuk, akkor a vizsgálati személyek eredményeit összevethetjük egymással, s akár rangsorolhatjuk is a csoporttagokat originalitás értékeik alapján. De: ha e feladatot mindössze egyetlen személy esetében használjuk, akkor nem tudjuk a válaszait mások (például csoporttagok) válaszaival összevetni... E problémát orvosolhatja, ha rendelkezésünkre áll egyfajta standard, amely tartalmazza az egyes válaszok pontszámait, előfordulási gyakoriságait. Magyarországon legalább két javaslat született e probléma megoldására.

Az originalitás pontozásának magyar variációi. Barkóczi és Klein (1968) az eredetitől eltérő (0-1 intervallumban mozgó) originalitás mutatót és hozzá tartozó standardot javasolt. Egy adott válasz Barkóczi-Klein-féle originalitás indexe (k-értéke) a következő formulával számítható ki: $\mathrm{k}=(1-(\mathrm{I}+\mathrm{i}) / 2 \mathrm{~T})^{14}$.

A képletben alkalmazott betük jelentése:

- $\quad \mathrm{k}$ : egy válasz originalitás pontszáma (minimum értéke $=0 ;$ maximum értéke $=1$ pont)

- T: egy kérdésre adott összes válasz száma

- I: egy témakörbe tartozó válaszok száma

- i: a szó szerint megegyező válaszok száma

- Megjegyzés: az indexet azért kellett magasabb hatványra emelni, hogy a 0-1 intervallumot jobban ki lehessen használni $(6,7,8,12,13,14$ hatvány kipróbálását követően végül a 14. hatványt választották a képlet alkotói).

Hogyan számolható ki egy válasz originalitás (k) értéke e formula alapján? Nézzünk egy példát: vizsgálati személyeink feladata legyen az, hogy találjanak ki minél több szokatlan használati lehetőséget egy téglával kapcsolatban! Ha ők összesen 100 választ adnak $(\mathrm{T}=100)$, amelyek 3 különböző témakörbe sorolható (legyen-e fogalmi kategóriák neve például: „fegyver”, „rajzolás” és „súly”), és ök 20 olyan választ adtak, melyeket a „rajzolás” kategóriába sorolhatunk $\left(\mathrm{I}_{\text {,rajzolás” }}=20\right)$, s ezek közül 5 válasz (például: „kréta”) szószerint megegyezett ( $\left.i_{, \text {,kréta” }}=5\right)$, akkor a „kréta” szó k-értéke az alábbiak szerint alakul:

$$
\mathrm{k}_{\text {,kréta" }}=\left(1-\left(\mathrm{I}_{, \text {,rajzolás" }}+\mathrm{i}_{, \text {,kréta” }}\right) / 2 \mathrm{~T}\right)^{14}=(1-(20+5) / 200)^{14}=(1-(25 / 200))^{14}=0,15421 \sim 0,16 .
$$

A Barkóczi-Klein-féle originalitás index alkalmazásával nagyszámú kreativitásvizsgálatot végeztek, s végül létrejött egy pontozási táblázat (Zétényi, 1989a,b), s Magyarországon e pontozási táblázat terjedt el, van használatban. Amikor egy kreativitástesztet értékelünk, kikereshetjük az egyes válaszokat és a hozzájuk tartozó k-értékeket a táblázatból, majd e kértékeket összesítve kapjuk meg a vizsgálati személy originalitás pontszámát. Például: ha valaki 3 választ adott („A téglát használhatjuk krétaként, fegyverként vagy súlyként”) és a válaszok k-értékei: 0,85 és 0,25 és 0,55 pontot érnek, akkor a személy originalitás pontszáma $=0,85+0,25+0,55=1,65$ pont lesz. Elméletileg a Barkóczi-Klein-féle originalitás mutató minimum értéke 0 ; maximum értéke pedig nem lehet több, mint a fluencia értéke (=az értékelhető válaszok száma). Az átlagos originalitás (=originalitás/fluencia) értéke pedig 0 és 1 között mozog a Barkóczi-Klein-féle értékelő táblák alkalmazása esetében. 
A Barkóczi-Klein-féle formula egy módosított változata a Gellénné-féle képlet (Gelléné, 1978): $\mathrm{k}=\left(\mathrm{p}^{*}(\mathrm{~T}-\mathrm{I}) / \mathrm{T}\right)+\left(\mathrm{q}^{*}(\mathrm{~T}-\mathrm{i}) / \mathrm{T}\right)^{\mathrm{N}}$.

A betük jelentése e képletben:

- $\quad \mathrm{k}$ : egy válasz originalitás pontszáma (minimum értéke $=0$; maximum értéke $=1$ pont)

- T: feladatonként az összes válasz száma

- I: az egy kategóriába kerülő válaszok száma

- i: az egyes válaszok előfordulásának száma

- $\mathrm{q}=1-\mathrm{p}, \mathrm{p}=0,1$ (ezek egyfajta súlyok)

- $\mathrm{N}$ : hatványkitevő a $0-1$ intervallum jobb kihasználása érdekében $(\mathrm{N}=14, \mathrm{~N}=12, \mathrm{~N}=$ 16 értékekkel tesztelve)

A módosításra azért volt szükség, mert a Barkóczi-Klein-féle originalitás indexben túl nagy szerepet kapott a kategória nagyság, s a súlyozással nagyobb jelentőséget lehet tulajdonítani az eredetiségnek (Kálmánchey, 1979). Mivel e formulához nem publikáltak pontozási táblázatot és standard értékeket, ez kevésbé vált közismertté.

Mi a helyzet a két korábban felvetett problémával? A fluencia originalitást befolyásoló hatásának kiküszöbölése érdekében a Barkóczi-Klein-féle és a Gelléné-féle pontozási rendszer esetében is kiszámíthatjuk a korábban már ismertetett átlagos originalitás (=originalitás/fluencia) értéket.

A második problémával kapcsolatban láthatjuk, hogy a Barkóczi-Klein-féle formula alapján rendelkezésünkre áll egyfajta pontozási táblázat és standard, s ezek segítenek vizsgálati személyeink teljesítményét mások teljesítményéhez viszonyítani. Meg kell azonban jegyeznünk három problémát mindezzel kapcsolatban:

- Egyrészt e pontozási táblák és standardok sosem lehetnek befejezettek... E táblázatok tételeinek listája folyamatosan növekszik, ahogy a vizsgálati személyeink újabbnálújabb válaszokat adnak. Előbb-utóbb mindig felmerül a kérdés, hogy hány pontot ér egy valóban újszerü, egyedi, a táblázatban még nem is szereplő válasz k-értéke? A rendelkezésre álló pontozási tábla nyújt egyfajta megoldást e problémára: ha nem találunk egy választ a táblázatban, akkor a k-érték automatikusan 0,90 (vagy ehhez közeli érték) lesz. Sajnos e „hibakezelés” vagy „kivétel kezelés” azonban nem elég tökéletes, mivel egy idő (mondjuk néhány évtized) után a 0,90 pontos tételek mennyisége számottevő mértékben megnövekedhet, sőt: akár túlsúlyba is kerülhet a kevésbé magas k-értékü válaszokhoz képest. Ugyanígy az is elöfordulhat, hogy egy, az értékelö táblázat alapján jelenleg $\mathrm{k}=0,90$ pontos válasz a jövőben nagyon is gyakorivá válik. Ilyen esetben pedig a válasz k-értékét idővel csökkenteni kell. Az elavult standard idővel tehát használhatatlanná válik, mert nem tud helyesen különbséget tenni a válaszok originalitása (k-értéke) között. Ez a lényege a második problémának:

- Mivel a pontozó táblázat tételei ( $=\mathrm{a}$ nyilvántartott válaszok) és ezek k-értékei megváltozhatnak egy idő után, néhány évente ezeket frissíteni, revideálni szükséges. A jelenleg rendelkezésre álló pontozási táblázatok (Zétényi, 1989a,b) azonban máris több, mint 20 évesek... A tesztek értékelésekor pedig látjuk, hogy megérett az idő az értékelő táblázat frissítésére.

- És végül: napjainkban ugyanazokat a pontszámokat alkalmazzuk valamennyi korcsoport esetében. Így kénytelenek vagyunk a gyerekek teljesítményét a felnőttekéhez hasonlítani, s fordítva... Az értékelő táblázatok frissítése az életkori (és nemi) standardok szempontjából is időszerü.

Összefoglalva: noha a kreativitásteszteket szeretnénk minél objektívebb és csalhatatlanabb mérőeszközöknek tekinteni, sajnos mégsem azok. A kreativitás (s azon belül: az originalitás) 
mérése mellett azonban becslő módszerek is rendelkezésünkre állnak - ezekről lesz szó a következő fejezetben.

\section{Az originalitás becslése kérdőívek és/vagy vélemények alapján}

A tesztelés egy lehetséges alternatívája a képességek (többnyire vélemények gyüjtésén alapuló) becslése. A vélemények gyüjtésének két gyakori módja:

a) Interjút készíthetünk a vizsgálati személlyel és/vagy kortársaival, tanáraival, szüleivel, barátaival stb. Azonban: ha ez egy elöre rögzített kérdéssort tartalmazó strukturált interjú, akkor ez tulajdonképpen a kérdőív felvétel egy speciális esetének tekinthető.

b) Az originalitást megbecsülhetjük (általában: önjellemző) kérdőívek alkalmazása révén is.

Iskolai körülmények között a tanulók gondolkodásának erdetisége elvileg tanári, kortársi vélemények alapján is megbecsülhető - ám az originalitásra vonatkozó teszteredmények és vélemények közötti korreláció igen gyenge. Egyik vizsgálatunkban (Mező, 2008) például a Körök teszt originalitás pontszáma és a tanulók $(\mathrm{N}=539)$ saját eredetiségükről öt fokú skálán jelzett véleménye közötti korreláció nem volt szignifikáns; s a tanáraik $(\mathrm{N}=39)$ véleménye a diákjaik originalitásáról is csak $\mathrm{r}=0,15(\mathrm{p}<0,05)$ szintü együttjárást mutatot a diákok Körök tesztben elért originalitás pontszámaival. E jelenség hátterében feltételezhető egyik ok a burkolt személyiségelméletek (például: miként járnak együtt a különböző kognitív és nonkognitív képességek) véleményekre gyakorolt hatása lehet. A tanulók, osztálytársaik és tanáraik (véleménygyüjtéses eljárás elemzése során feltárt) burkolt személyiségelméleteinek struktúrája nagyon hasonló egymáshoz, s ugyanakkor erősen különböző a teszteredmények alapján kirajzolódó képtől. Figyelemre méltó, hogy leginkább a pedagógusok implicit személyiségelmélete tér el a teszteredmények szerveződésétől (1. ábra).

1. ábra: A pedagógusok véleménye alapján kirajzolódó burkolt személyiségelmélet különbözik a teszteredmények közötti korrelációs struktúrától (Mezö, 2008). Rövidítések: I = intelligencia; $F=$ fluencia; $O=$ originalitás; $X=$ flexibilitás; $P=$ pszichoticizmus, $E=$ extroverzió, $N=$ neuroticizmus, $D=$ deviancia
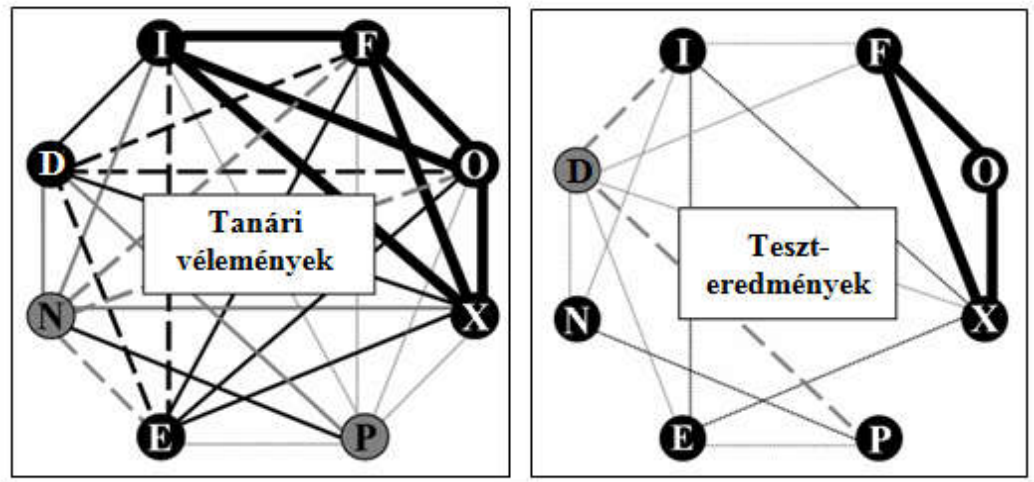

\begin{tabular}{|c|c|}
\hline Vonal és szin: & Jelentés ( $r=$ korrelá ciós egyiittható): \\
\hline & $r \geq 0,7$ \\
\hline & $0,5 \leq \mathrm{r} \leq 0,699$ \\
\hline$--ー--$ & $0,3 \leq \mathrm{r} \leq 0,499$ \\
\hline (n........................ & $r<0,3$ \\
\hline Nincs vonal: & $\mathrm{r}=0$ és/vagy a korreláció nem szignifikáns \\
\hline Fekete vonal: & Pozitív, szignifikáns $(p<0,05)$ korrelá ció \\
\hline Szürke vonal: & Negativ, szignifikāns $(p<0,05)$ korreláció \\
\hline Szürke korong: & Negativ korrelációk túlsúlya \\
\hline
\end{tabular}


Úgy tünik, hogy kognitív és nonkognitív személyiségváltozók korrelációira vonatkozó előfeltevések befolyásolhatják e változókról alkotott vélemények alakulását - többek között az originalitás esetében is.

Lényeges azonban, hogy noha a tesztek objektívebbek lehetnek a véleményeknél, de: a) a tesztek alkalmazása sokszor körülményes, nehezen illeszthető például az iskolai oktatás világába; b) a tesztek szakemberigényes eljárások, s ennélfogva: c) a tesztek iskolai alkalmazásukat tekintve költségesek lehetnek; s végül: d) érvényességük és megbízhatóságuk hagy kívánni valót maga után. Ugyanakkor ki kell emelni azt is, hogy amíg a tesztek néhány perces (felszólításra történő) kreatív munka eredményét értékelik; addig a vélemények akár több éves, nem csak felszólításra történő kreatív viselkedés megfigyelésének eredményeit összegezhetik. A véleménygyüjtésből és a tesztelésböl - mint a becslés és mérés két szélsőséges lehetőségéből - adódó problémák áthidalására kérdőíves adatgyüjtési eljárásokat is találunk az originalitás vizsgálatok palettáján.

Néhány kutató kérdőíveket, becslőskálákat dolgozott ki az originalitás (s más kreativitás változók) vizsgálatára. Néhány példa: Creativity Checklist (Johnson, 1979), Creative Behavior Inventory (Kirschenbaum, 1989), Group Inventory for Finding Creative Talent (GIFT - Rimm és Culbertson, 1980), Group Inventory for Finding Interests (GIFF I., II. Davis és Rimm, 1982), Creativity Styles Questionnaire (CSQ - Kumar, Kemmler és Holman, 1997), Abedi-Schumacher Creativity Test (CT - O’Neil, Abedi és Spielberger, 1944), Villa és Auzmendi Creativity Test (VAT - Auzmendi, Villa és Abedi, 1996), Iowa Inventiveness Inventory (Colangelo és tsai., 1992), Adjective Check Lists (ACL - Gough és Heilbrun, 1983). Ezeknek és az ezekhez hasonló eljárásoknak a rövid leírását és pszichometriai adatait Cropley (2003) foglalja össze.

Napjaink egyik modern kreativitást vizsgáló kérdőíves eljárása: a TKBS. Az alábbiakban azért mutatjuk be rövidden ezt az eljárást, mert:

- a TKBS egy új magyar (napjainkban még nem széleskörüen ismert) kreativitásbecslő kérdőív, s szeretnénk rá felhívni a figyelmet;

- a TKBS példáján keresztül szeretnénk illusztrálni az originalitás becslésének nehézségeit.

A Tóth-féle Kreativitást Becslő Skála (TKBS) egy 72 itemet tartalmazó, a válaszadásra ötfokú skálát alkalmazó önjellemző kérdőív (Tóth és Király, 2006). A TKBS összpontszámot az alábbi 12 skála összesítése adja (a magas pontszámok mutatnak a kreatív személyiség irányába):

- Nonkonformitás (NON): a magas pontszám nonkonformitásra utal.

- Komplexitás preferencia (KOM): a magas pontszám az összetett, bonyolult problémahelyzetek preferálására utal.

- Kockázatvállalás (KOC): a magas pontszám a kockázatvállaló; új, izgalmas, szokatlan helyzeteket kedvelö személyre utal.

- Önálló gondolkodás (GON): a magas pontszám a szellemi kihíváson, önálló felfedezésen alapuló ismeretszerzés kedvelésére utalnak.

- Türelmetlenség (TÜR): a magas pontszám türelmetlenségre utal.

- Önérvényesités (ÖNE): a magas pontszám a saját érdekekért való minden körülmények között történő kiállásra utal.

- Dominancia (DOM): a magas pontszám arra utal, hogy a válaszadó interperszonális kapcsolataiban kezdeményező, vezető szerepet igyekszik játszani.

- Kíváncsiság, érdeklödés (KÍV): a magas pontszám utal a kíváncsi, érdeklődő személyre.

- Energikusság (ENE): a magas pontszám lendületes, energikus személyre utal. 
- Eredetiség (ERE): a magas potszám utal az eredetibb, újszerübb gondolkodásra.

- Kitartás (KIT): a magas pontszám a feladat iránti elkötelezettségre, a kitartó, odaadó munkavégzésre utal.

- Játékosság, humor (JÁT): a magas pontszám humorérzékre, humor-produkcióra, játékos helyzetek preferálására utal.

A fent található skálák közül az „Eredetiség” tekinthető közvetlenül originalitást becslő skálának. Mint Tóth $(2011,68$. o.) e skála kapcsán írja: „Az eredetiség a kreativitás legrégebben azonosított, és leginkább felismerhető ismérve, a konvencióktól való elrugaszkodás képessége. Lényege, hogy egy adott kontextusban, problémahelyzetben olyan új megoldást talál a személy, mely a helyzetet adekvát módon, relatíve hatékonyabban oldja meg, és amelyre a többiek nem is gondoltak.” A TKBS „Eredetiség” skála megbízhatóságának vizsgálatakor Tóth és Király (2006; N=1732 fö) 0,78-as Cronbach- $\alpha$ értéket talált.

\section{Az originalitás méréses és becsléses vizsgálatának konkurens validitása}

A fentiek alapján láthatjuk, hogy az originalitás mérésére, illetve becslésére többek között teszteket és kérdöíveket is alkalmazhatunk. A következőkben tekintsük át a TKBS és két kreativitásteszt (a verbális jellegü Szokatlan használat teszt és a nonverbális jellegü Körök teszt) konkurens validitás vizsgálatának eredményeit! Vajon a becslő skálát alkalmazó TKBS kérdőív eredményei szorosan együttjárnak a (verbális és nonverbális) kreativitástesztek eredményeivel? Feltételezésünk szerint erös, pozitív korrelációs kapcsolatot találunk a különböző eszközökkel mért originalitás pontszámok között, mivel elvileg a kérdőív és a tesztek is ugyanarra a változóra (az originalitásra) fókuszálnak. Másrészt az is kérdés, hogy a két teszt originalitásra vonatkozó változói között erős korrelációs kapcsolatot találunk-e? Várakozásunk szerint a két teszt eredménye között még szorosabb korrelációt tapasztalhatunk, mint a teszt VS. kérdőív/becslő skála esetben.

Minta és módszer: vizsgálatunkban $(\mathrm{N}=) 127$ gimnazista (évfolyam: 9.; átlagéletkor: 14 év) töltötte ki a TKBS kérdőívet, illetve a Szokatlan használat (verbális kreativitás) tesztet és a Körök (nem verbális kreativitás) tesztet. Originalitás pontszámaikat az alábbiak szerint számoltuk ki:

- TKBS: a TKBS „Eredetiség” skáláját vettük figyelembe, s Tóth és Király (2006) pontozási rendszerét követve számoltuk ki az originalitás pontszámot. E skála lehetséges minimum értéke 0 pont; a maximuma pedig 24 pont (a magasabb pontszám jelent nagyobb originalitást). Tóth (2011) szerint a vizsgálati mintánkat alkotó 14 évesek esetében a TKBS e skálájának átlagértéke 12,2 pont, szórása 4,6 pont.

- Szokatlan használat teszt és Körök teszt: az originalitás és átlagos originalitás pontok számításakor a Barkóczi-Klein formulát alkalmazó 1989-es értékelő táblát alkalmaztuk (Zétényi, 1989a,b). E tesztek esetében az originalitás minimum értéke 0 pont; a vizsgálati személyek által elérhető elméleti maximum pedig a fluencia (az értékelhető válaszok) pontszámához közelítő érték. Az átlagos originalitás értéke 0-1 pont közötti lehet. A magasabb értékek jeleznek magasabb originalitást. Zétényi (1989a) alapján a 14 évesek átlagos teljesítménye a Körök-tesztben: az originalitás átlaga 5,67 $(\mathrm{SD}=2,89)$; az átlagos originalitás átlaga $0,37(\mathrm{SD}=0,63)$. A Szokatlan használat teszt esetében a 14 évesek originalitás pontszámának átlaga $5,07(\mathrm{SD}=1,16)$; az átlagos originalitás átlaga 0,29 $(\mathrm{SD}=0,10)$.

Az adatrögzítést és értékelést követően (a Kolmogorov-Smirnov próba alapján) t-próbával hasonlítottuk össze a vizsgálati mintánk átlagait a fent jelzett standardokkal, illetve Pearson- 
féle korrelációt számoltunk. A matematikai statisztikai számításokhoz az SPSS 13.0 for Windows-t használtuk.

Eredmények: elsőként a mintát alkotó tanulók eredményeit vessük egybe a kortársaikra jellemző átlagértékekkel (Tóth, 2011 és Zétényi, 1989a alapján). Az 1. táblázat foglalja össze az egymintás t-próba eredményeit. Vizsgálati személyeink három változó esetében értek el szignifikánsan $(\mathrm{p}<0,05)$ magasabb pontot; e változók: TKBS „Eredetiség” pontszám, a Szokatlan használat teszt átlagos originalitás értéke, és a Körök teszt átlagos originalitás értéke.

1. táblázat: vizsgálati személyeink eredményeinek egymintás t-próbával történö összevetése a rendelkezésre álló (Tóth, 2011 és Zétényi, 1989a) standardokkal.

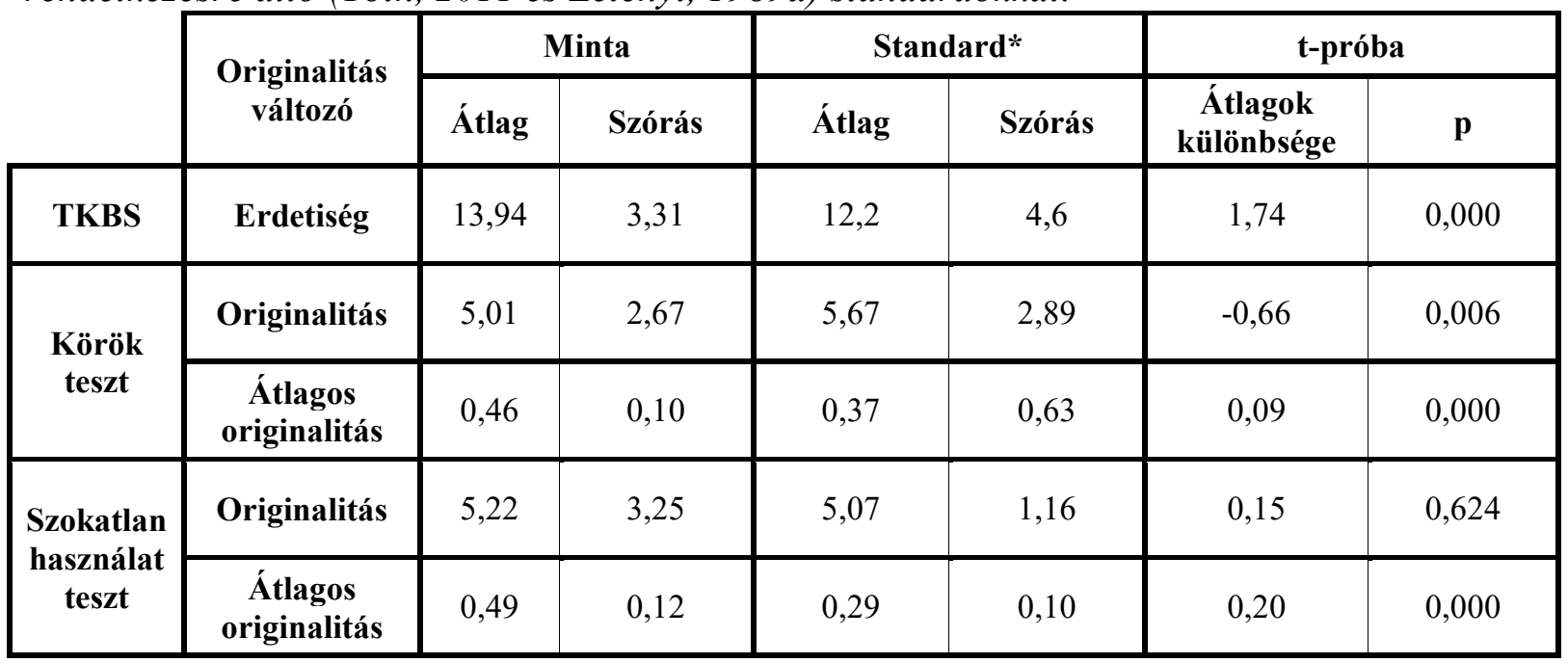

*A TKBS 14 évesekre vonatkozó standardja: Tóth (2011); a tesztek 14 évesekre vonatkozó standardjai: Zétényi (1989a) alapján.

A mintabeli személyek originalitás pontszámának átlaga ugyanakkor szignifikánsan $(p<0,01)$ alacsonyabb kortársaik átlagánál. A Szokatlan használat teszt esetében nem találtunk szignifikáns különbséget az originalitás pontszám tekintetében. Összefoglalva: vizsgálati mintánk TKBS-sel becsült originalitása magasabb, mint kortársaik becsült originalitása; s az átlagos originalitásra vonatkozó teszteredmények alátámasztják (de nem bizonyítják) e különbséget. Figyelemre méltó ugyanakkor, hogy amennyiben nem kezeljük a fluencia originalitás pontszámra gyakorolt hatását (vagyis: nem az átlagos originalitás, hanem az originalitás pontszámot vesszük tekintetbe), akkor a vizsgálati mintánk teszteredményei nem kiemelkedőbbek kortársaikénál.

Amint a 2. táblázat és a 2. ábra mutatja, hipotézisünk nem nyert megerősítést. Nem találtunk erős, pozitív korrelációs kapcsolatot a különböző originalitás változók között. Noha öt originalitás változónk között $(((5 \times 5)-5) / 2=) 10$ lehetséges kapcsolat van, jelen vizsgálatban mindössze 4-et $(\mathrm{r}=0,24-0,46 ; \mathrm{p}<0,01)$ tapasztaltunk.

A konkurens validitás szempontjából gyenge pozitív irányú szignifikáns korrelációt $(\mathrm{r}=0,23$ és 0,24 közötti; $p<0,01)$ figyelhetünk meg a TKBS „Eredetiség” skálája által becsült érték és a kreativitástesztek originalitás pontszámai között. Úgy tünik, hogy a TKBS alapján bizonyos mértékben előrejelezhető a mért originalitás, s fordítva. Tóth és Király (2006) hasonló tapasztalatokról számol be - vizsgálatunk megerösíti eredményeiket.

Az átlagos originalitás esetében nem találtunk szignifikáns korrelációt a TKBS és a tesztek között. Ezek szerint a TKBS „Eredetiség” pontszáma alapján jobban bejósolható az a fajta 
originalitás, amely az értékelhető válaszok számával van összefüggésben, mint az, amely az originális válaszokat az összes értékelhető válasz arányában veszi figyelembe.

2. táblázat: Pearson-féle korrelációk a TKBS „Erdetiség” skálájának pontszáma és a Körök teszt, illetve Szokatlan használat teszt originalitás és átlagos originalitás pontszáma között.

\begin{tabular}{|c|c|c|c|c|c|c|c|}
\hline & & & \multirow{2}{*}{$\begin{array}{c}\text { TKBS } \\
\text { Erdetiség }\end{array}$} & \multicolumn{2}{|c|}{ Körök teszt } & \multicolumn{2}{|c|}{$\begin{array}{c}\text { Szokatlan használat } \\
\text { teszt }\end{array}$} \\
\hline & & & & Originalitás & $\begin{array}{c}\text { Átlagos } \\
\text { originalitás }\end{array}$ & Originalitás & $\begin{array}{c}\text { Átlagos } \\
\text { originalitás }\end{array}$ \\
\hline \multirow{2}{*}{ TKBS } & \multirow{2}{*}{ Eredetiség } & $\mathbf{r}$ & 1 & $0,235^{*}$ & $-0,060$ & $0,242 *$ & 0,046 \\
\hline & & $\mathbf{p}$ & & 0,009 & 0,513 & 0,007 & 0,612 \\
\hline \multirow{4}{*}{ 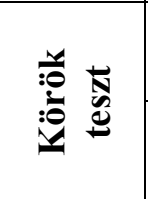 } & \multirow{2}{*}{ Originalitás } & $\mathbf{r}$ & $0,235^{*}$ & 1 & $0,311^{*}$ & 0,126 & $-0,077$ \\
\hline & & $\mathbf{p}$ & 0,009 & & 0,000 & 0,160 & 0,391 \\
\hline & \multirow{2}{*}{$\begin{array}{c}\text { Átlagos } \\
\text { originalitás }\end{array}$} & $\mathbf{r}$ & $-0,060$ & $0,311^{*}$ & 1 & $-0,031$ & $-0,030$ \\
\hline & & $\mathbf{p}$ & 0,513 & 0,000 & & 0,735 & 0,736 \\
\hline \multirow{4}{*}{ 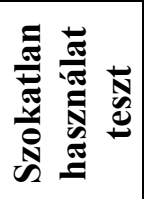 } & \multirow{2}{*}{ Originalitás } & $\mathbf{r}$ & $0,242 *$ & 0,126 & $-0,031$ & 1 & $0,458 *$ \\
\hline & & $\mathbf{p}$ & 0,007 & 0,160 & 0,735 & & 0,000 \\
\hline & \multirow{2}{*}{$\begin{array}{c}\text { Átlagos } \\
\text { originalitás }\end{array}$} & $\mathbf{r}$ & 0,046 & $-0,077$ & $-0,030$ & $0,458^{*}$ & 1 \\
\hline & & $\mathbf{p}$ & 0,612 & 0,391 & 0,736 & 0,000 & \\
\hline
\end{tabular}

* Szignifikáns korreláció $(\mathbf{p}<0,01)$

2. ábra: Várható és megfigyelt szignifikáns $(p<0,05)$ korrelációk a TKBS, a Körök teszt és a Szokatlan használat teszt originalitás változói között. A vastagabb vonal erösebb korrelációt szimbolizál.

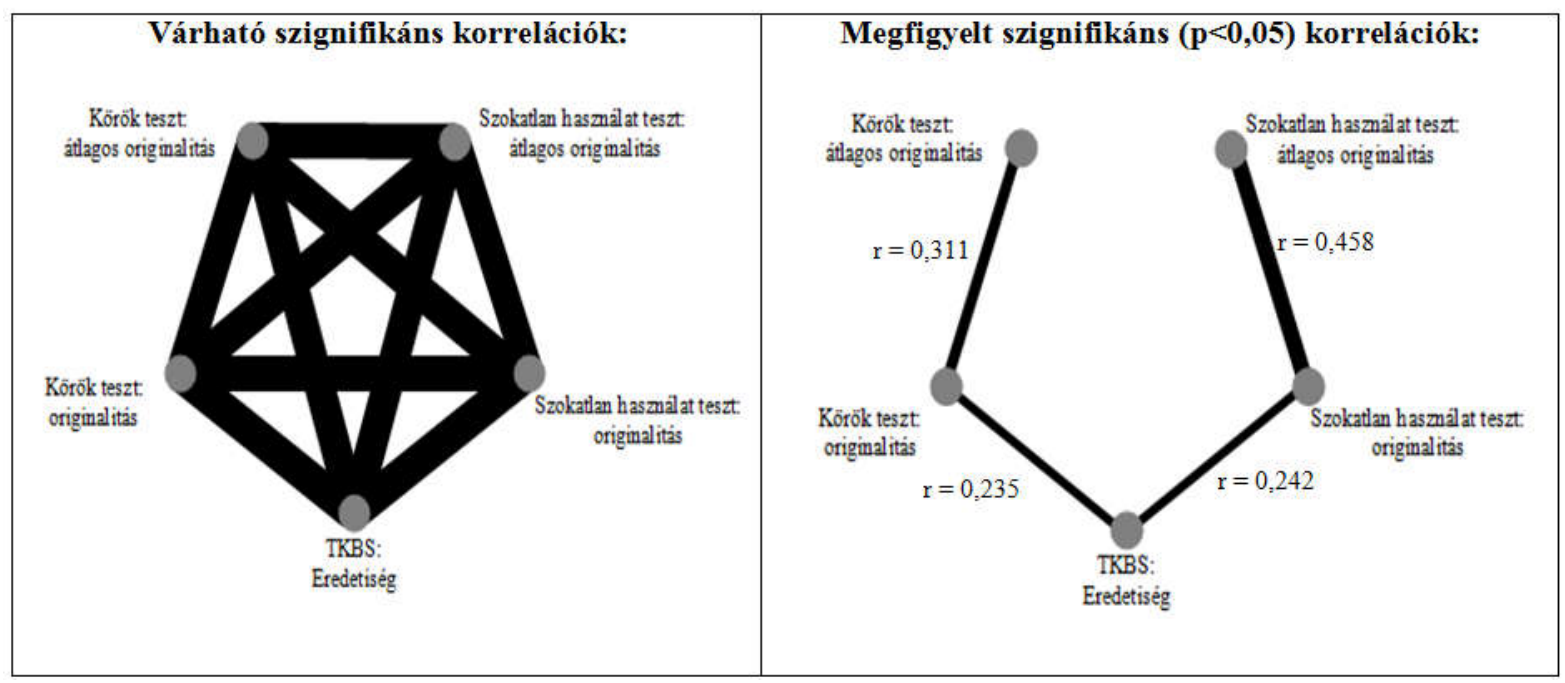

Figyelemre méltó, hogy a verbális (Szokatlan használat) és a figurális (Körök) kreativitástesztek originalitás és átlagos originalitás értékei nem korrelálnak egymással. Sőt: eredményeink szerint a TKBS-nek több köze van a tesztek originalitás pontszámához, mint a két tesztnek egymáshoz. 
Az originalitás és átlagos originalitás változók között a Körök teszt esetében $r=0,311$; a Szokatlan használat teszt esetében $\mathrm{r}=0,458$ értékü szignifikáns $(\mathrm{p}<0,05)$ korrelációs kapcsolatot találtunk. Ez jelzi, hogy van ugyan együttjárás egy-egy teszten belül a kétféle originalitás érték között, de az nem igazán erős. A magas originalitás érték tehát nem feltétlenül jár együtt a magas átlagos originalitás értékkel. Ennek gyakorlati következménye lehet, hogy a vizsgálati személyek originalitás pontszám, illetve átlagos originalitás pontszám szerint homogénnek tekinthetö csoportjaiba nem teljesen ugyanazokat a személyeket válogathatjuk be (például egy feltételezett tehetséggondozó programba történő beválogatás során).

\section{ÖSSZEFOGLALÁS}

Jelen tanulmányban az originalitás mérésének és becslésének néhány porblémájára irányítottuk a figyelmet. Elöször bemutattuk és összevetettük az originalitás néhány különböző pontozási lehetőségét, majd kitértünk az originalitás becslésének lehetőségére.

A tanulmány második részében saját vizsgálatunkat és annak eredményeit foglaltuk össze. Központi témánk a mért vagy becsült originalitás közötti korreláció vizsgálata volt. Vizsgálatunkban 127 gimnazista (átlagéletkor: 14 év) töltötte ki a Tóth-féle Kreativitást Becslő Skálát (TKBS-t), illetve a Szokatlan használat tesztet és a Körök tesztet. Prezentációnkban a TKBS „Eredetiség” skálájának eredményeit vetettük össze a tesztek originalitás és átlagos originalitás változóival. Alkalmazott matematikai statisztikai eljárások: Kolmogorov-Smirnov próba, egymintás t-próba, Pearson-féle korreláció. Az adatokat az SPSS 13.0 for Windows szoftverrel számoltuk ki. Eredményeink szerint a TKBS „Eredetiség” skálája alapján (bár gyengén, mégis) jobban bejósolható a kreativitástesztek originalitás pontszáma, mint ahogy a két teszt egymás originalitás értékeit bejósolni képes.

Egyetértünk a Tóth és Király (2006) szerzőpárossal, miszerint a TKBS a kreatív problémamegoldó folyamat feltárásának komplex és hasznos eszköze, mely segítséget nyújt a tanároknak abban, hogy tájékozódjanak tanulóik kreativitását illetően.

\section{IRODALOM}

Auzmendi, E., Villa, A., Abedi, J. (1996): Reliability and validity of a newly constructed multiple-choice creativity instrument. Creativity Research Journal, 9, 89-96.

Barkóczi, I., Klein, S. (1968): Gondolatok az alkotóképességről és vizsgálatának egyes problémáiról. In Magyar Pszichológiai Szemle, 1968/4, 508-515.

Colangelo, N., Kerr, B., Hallowell, K., Huesman, R., Gaeth, J. (1992): The Iowa inventiveness inventory: Toward a measure of mechanical inventiveness. Creativity Research Journal, 5, 157-163

Cropley, A. J. (2003): Creativity in the education and learning. A guide for teachers and educators. London: Kogan Page.

Davis, G. A., Rimm, S. B. (1982): Group Inventory For Finding Interests (GIFFI I and GIFFI II): Instruments for Identifying Creative Potential in Junior and Senior High Schools. Journal of Creative Behavior, 16 (1), 50-57.

Dow, G.T., Mayer, R.E. (2004): Teaching students to solve insight problems. Evidence for domain specificity in training. Creativity Research Journal, 16,4 389-402.

Johnson, D. L. (1979): The Creativity Checklist. Wood Dale: Stoelting.

Gelléné, K. M. (1978): A kreativitás kapcsolata az intelligenciával, tanulmányi eredménnyel, szociális és szociometriai tényezőkkel ötödik osztályos tanulóknál. In Acta Pedagogica Debrecina, 1978, 73. szám 
Guilford, J. P. (1962): Creativity: Its measurement and development. In J. J. Parnes and H. F. Harding (eds.) A source book for creative thinking. New York: Scribners.

Guilford, J.P. (1967): The Nature of Human Intelligence. McGraw-Hill Education

Gough, H. G., Heilbrun, A.B. jr.(1983): The Adjective Check List Manual (2nd edition). Palo Alto, CA: Consulting Psychologist Press Services

Kálmánchey, M. (1979): A Torrance-teszt alkalmazásának tapasztalatai ötödik osztályosoknál. Magyar Pszichológiai Szemle, 1979/2. 161-170.

Kirschenbaum, R. J. (1989): Understanding the Creative Activity of Students. Mansfield: Creative Learning Press.

Kumar, V. K., Kemmler, D., Holman, E. R. (1997): The Creativity Styles Questionnaire revised, Creativity Research Journal, 10, 51-58.

Mednick, S. A. (1962): The associative basis of the creative process. Psychological Review, 69, 220-232.

Mező, F. (2008): Tests or Opinions? A Problem of Identification of Giftedness. In Mező, F., Péter-Szarka, Sz.(eds.): Psychological Aspects of Gifted Education. Kocka Kör \& Department of Educational Psychology of University of Debrecen, Debrecen. 15-26.

Mező, F. (2013): Measurement and estimation of originality. In: Angyalosi, G., Münnich, Á. és Pusztai, G. (eds.): Interdisciplinary Research in Humanities. Nitra: Constantine the Philosopher University in Nitra, Faculty of Central European Studies. pp. 457-472.

Mérei, F. (2002): Rorschach-próba. Medicina Könyvkiadó Rt., Budapest.

O'Neil, H. F., Abedi, J., Spielberger, C. D. (1944): The measurement and teaching of creativity. In O'Neil, H. F, Drilligs, M. (eds.): Motivation: Theory and Research. New Jersey: Erlbaum, Hillsdale, 245-263.

Rimm, S., Culbertson, F. (1980): Validation of GIFT, an instrument for the identification of creativity. Journal of Creative Behavior, 14 (4), 272-273.

Süle, F. (1988): A „Fa-rajz”-teszt. In Mérei, F., Szakács, F. (eds.): Pszichodiagnosztikai Vademecum. II. Személyiségtesztek 2. rész. Tankönyvkiadó, Budapest. 89-148.

Szőnyi, M.(1988): Jacqueline Royer Metamorfózisok tesztjének diagnosztikus alkalmazása, valamint 300 budapesti gimnazista jegyzőkönyvének feldolgozása. In Mérei, F., Szakács, F. (eds.): Pszichodiagnosztikai vademecum II. Személyiségtesztek 3. rész. Tankönyvkiadó, Budapest. 99-159.

Torrance, E. P. (1966): Torrance tests of creative thinking (Research ed.). Princeton, NJ: Personnel Press.

Wallach, M. A., Kogan, N. (1965): Modes of Thinking in Your Children: A Study of the Creativity-intelligence Distinction. New York: Holt, Rinerhart \& Winston.

Tóth, L. (2011): A Tóth-féle Kreativitás Becslő Skála (TKBS). In Münnich, Á. (ed.): $A$ kreativitás többszempontú vizsgálata. Didakt Kiadó, Debrecen. 65-88.

Tóth, L., Király, Z. (2006): Új módszer a kreativitás megállapítására: A Tóth-féle Kreativitás Becslő Skála (TKBS). Magyar Pedagógia, 106, 2006/4, 287-311.

Zétényi, T. (1989a): A Kreativitás-tesztek tesztkönyve I. Munkalélektani Koordinációs Tanács Módszertani Sorozata, 22. kötet. Munkaügyi Kutatóintézet, Budapest.

Zétényi, T. (1989b): A Kreativitás-tesztek tesztkönyve II. Munkalélektani Koordinációs Tanács Módszertani Sorozata, 22. kötet. Munkaügyi Kutatóintézet, Budapest. 